\title{
The Problem of Characterizing the 4QReworked Pentateuch Manuscripts: Bible, Rewritten Bible, or None of the Above? ${ }^{1}$
}

\author{
Molly M. Zahn \\ University of Notre Dame
}

The group of texts from Qumran known as 4QReworked Pentateuch (4Q158, 4Q364367) has since its official publication in the mid-1990s eluded precise characterization by scholars. Already before its publication John Strugnell had referred to the texts as a "rogue" or "wild" Torah, ${ }^{2}$ and Yigael Yadin had identified several fragments of one of the manuscripts as belonging to a copy of the Temple Scroll. ${ }^{3}$ But the touchstone of the debate in recent years has been the issue of whether the $4 \mathrm{QRP}$ texts should be regarded as expanded editions of the Torah or as nonbiblical works of the category "rewritten Bible." The manuscripts largely contain the text of the Pentateuch that is familiar to us from the ancient versions (the Samaritan in particular), but also at times incorporate substantial new material or present the text in a new sequence. As a result of their deviations from the known versions, the initial editors, Emanuel Tov and Sidnie White Crawford, classified the $4 \mathrm{QRP}$ texts as nonscriptural, non-authoritative, interpretive works. ${ }^{4}$ This assessment has been challenged separately by Eugene Ulrich, James VanderKam, and Michael Segal, on the basis of the rich variation in versions of the biblical text that the Qumran discoveries have revealed. In their minds, precisely the sorts of exegetical additions and reorganizations that prompted the original editors to classify the 4QRP texts as nonscriptural are characteristic of the emergent biblical text in the late Second Temple period. ${ }^{5}$ Thus, for Segal, some, and for Ulrich and VanderKam, all of the 4QRP manuscripts should be considered copies of the Pentateuch rather than copies of extrabiblical compositions. ${ }^{6}$ More recently, Tov has changed his position and argues that, 
on the basis of their parallels to the "rewritten" forms of some books in the LXX, the 4QRP texts should be regarded as "Hebrew Scripture."7 On the other hand, the nonbiblical status of the manuscripts has continued to be defended, especially by Moshe Bernstein. $^{8}$

Further progress in the debate over the status of the 4QRP texts has been slowed, in my opinion, by several factors. First, the parallels between the editorial activities evident in the 4QRP texts and in manuscripts and versions of biblical books have been noted but not clearly demonstrated. Second, the significance of such parallels for the status of the 4QRP texts has not been considered in relation to other factors that may be important, such as the content and literary features of the texts. Third, in an important article that lays down criteria for determining whether a given text is an edition of a biblical book or a nonbiblical composition, Michael Segal assumes the biblical status of 4Q364-367, and thus does not consider how well his valuable criteria fit the 4QRP texts. ${ }^{9}$ In what follows, I will bring all these threads together in the hopes of defining more clearly the factors that might help determine how we should classify the 4QRP texts.

Two caveats must be mentioned before going further. First, I recognize the difficulty involved in applying the label "biblical" to texts circulating in the era before "the Bible" as we know it - a collection of specific forms of specific books, and only those books - came into existence. ${ }^{10}$ It has been argued by several scholars that, because of this anachronism, the terms "Bible" and "biblical" should not be employed in relation to works of the Second Temple period. ${ }^{11}$ These scholars tend to use the terms "Scripture" and "scriptural" instead, terms that avoid the anachronism and have the advantage, as VanderKam and Flint point out, of reflecting the frequent use in the Scrolls of the root 
כתב to refer to or cite sacred literature. ${ }^{12}$ Their point is well-taken, but employment of the term "scriptural" creates a serious terminological ambiguity with regard to the question I wish to address here. The difficulty is that, however the term "scriptural" is defined in its particulars, use of that term for religious texts implies value, an attribution to a text of some sort of sacredness or divine authority. ${ }^{13}$ This valuation as sacred is not my concern here. The question whether the 4QRP texts represent variant editions of the Pentateuch is not (in the first place) a question about their sacred status, for they could have been regarded as sacred or inspired whether they were copies of the Pentateuch or not. Indeed, one of the objections to the use of the term "biblical" at Qumran is that it seems that at least some other works that never became part of the Hebrew Bible (such as Jubilees and perhaps 1 Enoch) were also regarded as sacred, as "scriptural," by that community. ${ }^{14}$ Rather, the issue is the literary relationship between the 4QRP texts and the literary works that later became parts of our Bible as the five books of the Torah. Do the 4QRP texts represent an alternative version or new edition of Genesis, Exodus, Leviticus, Numbers, and Deuteronomy, or do they constitute a different work altogether? Since the term "Scripture" refers primarily to the value a community places on a work and does not adequately reflect this notion of literary identity, I avoid it in what follows. For lack of any other clear option ("variant edition of the Pentateuch" quickly becomes very clumsy), I use the term "biblical." By employing this term, I do not mean to imply that there was anything like a Bible in the traditional sense at the time the $4 \mathrm{QRP}$ texts were composed. Instead, I am using "biblical" as a shorthand designation for a (version of a) literary work that later became part of the Hebrew Bible. 
Second, while Tov and Crawford took the five manuscripts 4Q158 + 4Q364-367 to be copies of a single composition (4QRP $\left.{ }^{\mathrm{a}-\mathrm{e}}\right)$, I am generally persuaded by the arguments of Segal and George Brooke that the evidence for considering all five manuscripts to be copies of a single work is minimal. ${ }^{15}$ There are very few actual overlaps among the manuscripts, and when they do overlap the text in question is most often simply the text of the Pentateuch familiar to us from elsewhere. ${ }^{16}$ Overlaps in readings unique to the $4 \mathrm{QRP}$ manuscripts are extremely minor. ${ }^{17}$ The lack of substantive overlap means that the primary evidence cited by the editors in their argument for a single composition is the similar treatment of the biblical text in all five manuscripts. ${ }^{18}$ But such an argument is much too general to be persuasive. ${ }^{19}$ Furthermore, at times parallel passages even show evidence of substantial divergence. ${ }^{20}$ As a result, it is most likely that we are dealing with five different (albeit similar) compositions rather than one. To reflect this probability, when I intend to refer to the composition or compositions reflected in the five $4 \mathrm{QRP}$ manuscripts, I refer to "the $4 \mathrm{QRP}$ texts" instead of to a single text called $4 \mathrm{QRP} .^{21}$

\section{Treatment of the Pentateuchal Vorlage}

The departures in content and sequence in the $4 \mathrm{QRP}$ texts from the text of the Pentateuch as attested elsewhere have attracted a good deal of attention, and rightly so. Yet it should be kept in mind that most of the manuscript fragments of the $4 \mathrm{QRP}$ texts simply contain the text of the Pentateuch with minor or no variation..$^{22}$ The Vorlage used by the editor(s) of the text(s) reflected in at least two of the manuscripts, 4Q158 and 4Q364, must have been a pre-Samaritan text of the Pentateuch: several of the distinctive features of that text-type, such as the insertion of material from Deuteronomy 5 and 18 into the Exodus 
20 version of the Decalogue, appear in those two manuscripts, and in minor variants 4Q158 and 4Q364 exhibit more affinity with SP than with other text-types. ${ }^{23}$

It is the contention of VanderKam, Ulrich, Segal, and now Tov that the additions and rearrangements unique to the $4 \mathrm{QRP}$ texts are also consistent with the types of changes that we find empirically attested in manuscripts and versions of biblical books. Though an exhaustive analysis of the changes made by the editors of the 4QRP texts cannot be conducted here, a brief overview of these two general categories, additions and rearrangements, will be adequate to demonstrate the accuracy of this claim.

Additions extant in the manuscripts of the 4QRP texts vary in size from a few words to multiple lines and even whole sections, if the evidence of 4Q365a is taken into account. A moderately sized example is the addition in 4Q158 1-2 of a blessing into the account of Jacob's struggle with the "man" at the Wadi Jabbok (Gen 32:25-33). The editor of the composition reflected in 4Q158 seems to have been troubled by the fact that Genesis records that the "man" blessed Jacob (ויברך אתו שם, Gen 32:30), but does not include the words of this blessing. ${ }^{24}$ Thus, after the conclusion of Gen 32:30, he adds a blessing, even including a Wiederaufnahme that marks the end of the new material: ${ }^{.25}$

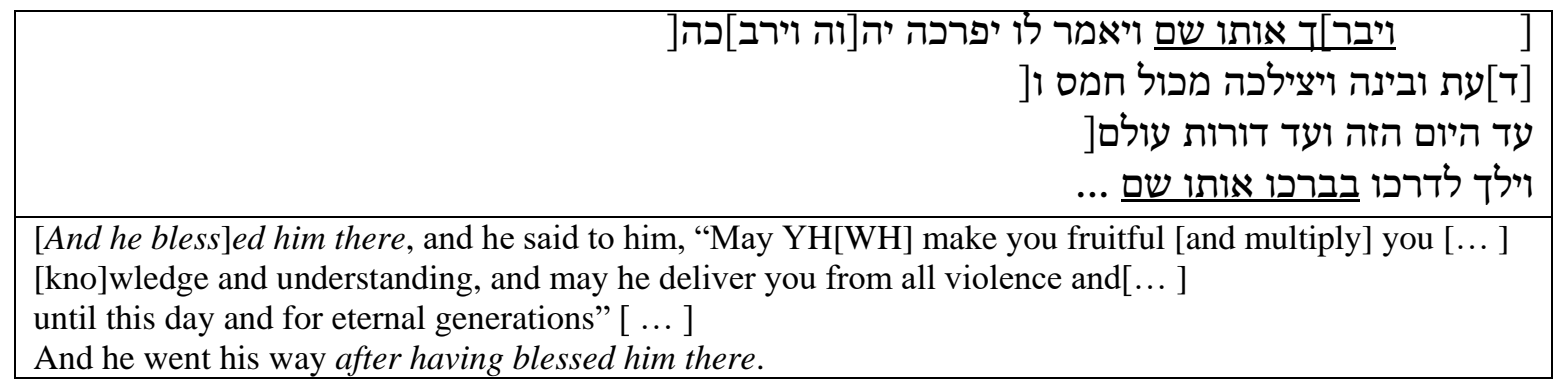

\section{Q158 1-2 7-10: Addition to Gen 32:3026}

More extensive additions are found in the so-called "Song of Miriam" (4Q365 6), inserted before Exod 15:22 in apparent response to the abbreviated nature of Miriam's 
song in the text of Exodus; ${ }^{27}$ and in $4 \mathrm{Q} 36523$, where a paragraph on the wood offering and the Festival of New Oil has been appended to the festival calendar of Leviticus $23 .{ }^{28}$ Finally, in 4Q365a, which I believe must be regarded as part of 4Q365, there are extant parts of two columns dealing with the building of a temple court. ${ }^{29}$ Needless to say, there is no pentateuchal parallel for such legislation, though the text does overlap with 11QT columns 38 and 41 . Since instructions for building a temple court seem unlikely unless accompanied by instructions for the temple building itself, 4Q365 seems to have contained an addition of at least several columns to the text of the Pentateuch as attested elsewhere.

Numerous comparable additions, of various lengths, have been preserved in the textual witnesses of the Bible. A shorter plus comparable in size to the first example from the 4 QRP texts given above (4Q158 1-2) can be found in Judg 6:7-10. These verses interrupt the story of Israel's oppression by the Midianites and the subsequent appearance of God's messenger to Gideon with a thoroughly deuteronomistic paragraph that records the sending of "a prophet" (6:8) to announce to the people that they have disobeyed God's command (6:10). Wellhausen's identification of these verses as an insertion belonging to the last layer of redaction finds support in $4 \mathrm{QJudg}^{\mathrm{a}}$, which lacks the passage. ${ }^{30}$ Longer additions that might be adduced include the alternate version of the David and Goliath story in 1 Samuel 16-18 and the oracle concerning the house of David in Jer 33:14-26; both of these texts are present in the MT but lacking in LXX. ${ }^{31}$ Addition of even larger sections is attested for the books of Daniel and Esther, whose texts were still fluid enough at the time of their translation into Greek to admit substantial amounts of new material. ${ }^{32}$ 
Rearrangements, where the biblical text is presented in a sequence different from that of known biblical versions, occur with some frequency in the five 4QRP manuscripts. In several cases, the purpose of the rearrangement is manifest: to bring together legislation or narrative dealing with similar topics. For instance, 4Q366 groups at least some of the biblical laws on the festival of Sukkot, with frag. 4 presenting the Deuteronomic version of the law (Deut 16:13-14) immediately following the Priestly version and the conclusion to the Priestly festival calendar (Num 29:12-30:1).

\begin{tabular}{|c|}
\hline 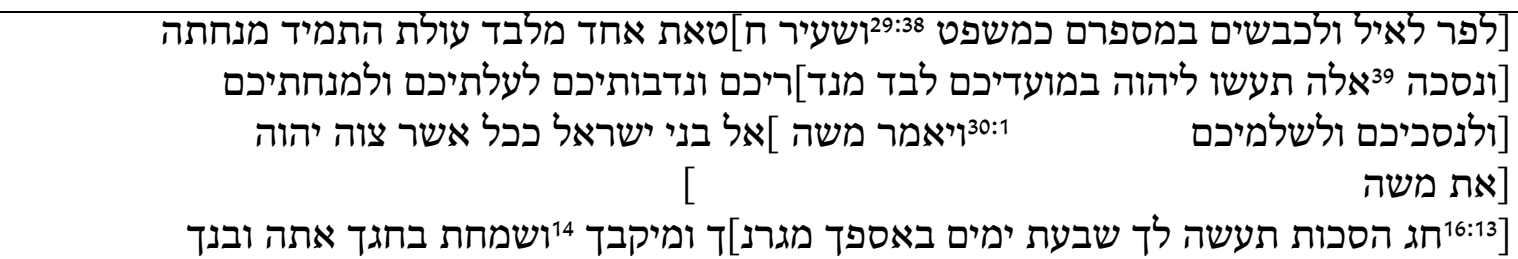 \\
\hline $\begin{array}{l}\text { [Num 29:37... for the bull, for the ram, and for the lambs in their number, according to the ordinance, }{ }^{38} \text { and] } \\
\text { one [goat for a pu]rification offering, apart from the daily burnt offering, its grain offering [and its drink } \\
\text { offering. }{ }^{39} \text { These you shall offer to YHWH on your appointed feasts, apart from] your [vo]ws and your } \\
\text { free-will offerings, for your burnt offerings and for your grain offerings [and for your drink offerings and } \\
\text { for your offerings of well-being. } \\
\text { everything which YHWH commanded [Moses. } \\
\text { [Deut 16:13 } \text { And Mou shall observe the festival of Sukkot for seven days when you gather in from] your [threshing- }\end{array}$ \\
\hline
\end{tabular}

\section{Q366 4 i 6-10: Joining of Laws on Sukkot}

A similar rearrangement can be found in $4 \mathrm{Q} 36528$, where the narrative of Numbers 4 is followed directly by the continuation of the narrative in Numbers 7 (thus the legal material in chs. 5 and 6 has been omitted or relocated).

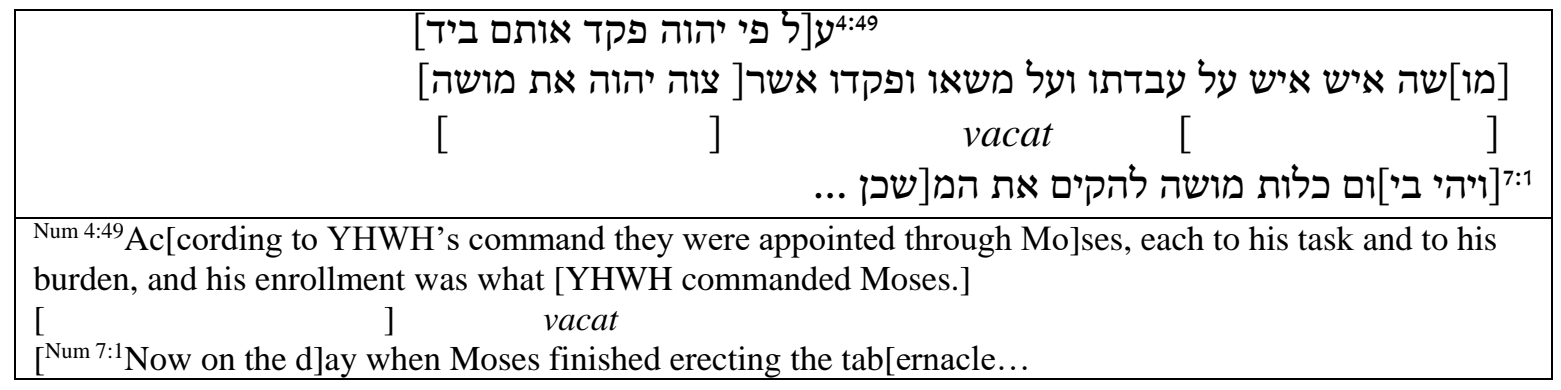

4Q365 28 2-5: Numbers 4 Joined to Numbers 7 
Finally, in 4Q365 36, the two biblical episodes concerning the daughters of Zelophehad (Num 27:1-11;36:1-12) have been juxtaposed so that Num 36:1 follows Num 27:11 without so much as a paragraph break. ${ }^{33}$

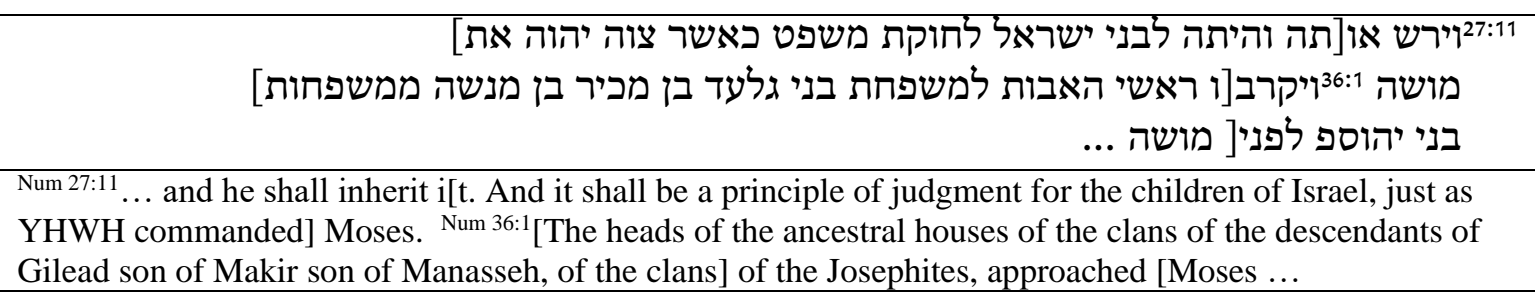

\section{Q365 36 2-4: Two Pericopes on Zelopehad's Daughters Joined}

Other instances of rearrangement lack such a clear motivation; for example, the juxtaposition in 4Q366 2 of the law of talion (Lev 24:20-22) and the law regulating debtslavery for Israelites (Lev 25:39-44) ${ }^{34}$; and the move in 4Q367 2 from the end of the law concerning a man with a discharge (Lev 15:14-15) to the beginning of the Holiness Code's ethical prescriptions (Lev 19:1).

Instances of large-scale reordering are also attested in recognized versions of the biblical text. Two well-known examples involve the narrative of the construction of the tabernacle in Exodus 35-40 and the oracles against the foreign nations in Jeremiah 4651. In each case, LXX differs greatly from MT in sequence. ${ }^{35}$ Each case has also been the object of continued debate as to which form of the text is more original. For my purposes, the resolution of this debate is of secondary importance; the main point is the realization that, at some point in the textual histories of both Exodus and Jeremiah, a thoroughgoing rearrangement took place that led to the two different traditions preserved today. ${ }^{36}$

This brief glance has provided clear evidence for the position that the textual changes found in the five 4QRP manuscripts are consistent with the treatment of biblical texts in the Second Temple period. Such an observation is significant in that it leads to 
the conclusion that, generally speaking, the $4 \mathrm{QRP}$ manuscripts should not be distinguished qualitatively from biblical manuscripts on the basis of their degree of departure from the text of the Pentateuch as it has come down to us. That is, there is nothing about the reworking in these texts that prevents them from being expanded editions of the Pentateuch. On the other hand, such evidence does not constitute proof that the 4QRP manuscripts are in fact copies of the Pentateuch. This is the case because the same parallels in treatment of the biblical text could also be drawn between accepted biblical versions and texts that are manifestly not copies of biblical books, such as Jubilees and the Temple Scroll. ${ }^{37}$ For example, the topical rearrangement of biblical law is one of the hallmarks of the Temple Scroll's reworking of the Pentateuch, and that reworking is also replete with additions (such as the extended Law of the King in 11QT $56-59) \cdot{ }^{38}$

This is not to say that all reworkings of biblical books in the late Second Temple period are equal, or to deny the idea of a "continuum" of revision of the pentateuchal source from minimal (the pre-Samaritan texts, for example) to maximal (Jubilees and beyond) ${ }^{39}$ Indeed, a more precise characterization of the various types or degrees of rewriting of the Pentateuch in this period is urgently needed. But the identification of such a continuum, or an individual text's place upon it, does not answer the question of whether that text was considered a copy of the book or books it rewrote, as has been argued persuasively by Michael Segal. ${ }^{40}$ The fundamental reason for this is the variation shown in the transmission history of the books of the Bible themselves: the textual histories of Jeremiah and Daniel, for instance, show that drastic changes did not disqualify a new edition of a book from being considered an authentic copy of that 
book. ${ }^{41}$ To put it another way, rearrangements and additions to an existing Vorlage did not necessarily require that the new text be considered a separate literary work, as opposed to an updated or expanded version of the original text.

\section{Other Criteria: Voice, Scope, and Coverage}

If analysis of the degree and manner of reworking of the source text is not sufficient to determine whether the $4 \mathrm{QRP}$ texts represent new editions of the Pentateuch, we need to turn to other criteria for help. Segal, in his recent examination of how one distinguishes a composition of the genre "rewritten Bible" from a copy of a biblical book, has proposed several criteria that I think are especially relevant to the $4 \mathrm{QRP}$ texts. ${ }^{42}$ The first of these is narrative voice: rewritten texts tend to provide themselves with a new voice and setting that serves to distinguish them from their predecessor and provide them with their own, independent authority. The Temple Scroll, for instance, distinguishes itself from the text of Deuteronomy that it reworks by presenting God as the speaker, not Moses as in the source text. Similarly, Jubilees constructs its own narrative voice by casting the Angel of the Presence as speaker. ${ }^{43}$ The second criterion is scope: Segal points out that new editions of biblical books tend to start and stop in the same place as their predecessors. Rewritten Bible compositions, on the other hand, frequently deviate from the scope of the works they draw upon. ${ }^{44}$ Thus for example the MT and LXX versions of Jeremiah both begin with the prophet's call and end with the destruction of Jerusalem, despite considerable differences in sequence and content in between. By contrast, Jubilees covers the Pentateuch from Genesis 1 to approximately Exodus 24. The Temple Scroll begins in the middle of the book of Exodus, at Sinai, and covers only parts of Leviticus, Numbers, and Deuteronomy, omitting all narrative, before ending with material from Leviticus 18 
and $20 .{ }^{45}$ Finally, a criterion related to scope is coverage within the bounds of the composition. Segal argues that new editions of biblical books tend not to omit material, but rather tend towards expansion, while the authors of rewritten Bible texts feel free both to expand and to contract their source. ${ }^{46}$

In the article where he develops these criteria, Segal treats 4Q364-367 as copies of the Pentateuch, and thus does not actually examine them in the light of his own criteria. His conclusion that 4Q364-367 are biblical manuscripts is based upon an earlier article, in which he argues that these four manuscripts should be considered biblical because their reworkings of their pentateuchal Vorlage "follow precedents of textual transmission found within the Hebrew Bible itself. ${ }^{97}$ As we have seen, however, Segal himself argues that the type or degree of reworking found within a text cannot settle the question of whether that text was intended as an edition of a biblical book. A closer look is therefore necessary to see how the criteria that Segal has delineated in fact apply to the $4 Q R P$ texts.

With regard to voice, the data seem fairly clear. In striking contrast to the Temple Scroll and Jubilees, the preserved 4QRP manuscripts give no indication of "speaking" with any voice besides the one found in the Bible. Insofar as the 4QRP texts claim sacred status or authority, they seem to make this claim through their use of the voice of Torah, as Crawford has pointed out. ${ }^{48}$ In at least one case, the editor deliberately extends the voice of the source text to new material: in $4 \mathrm{Q} 36523$, the new legislation on the wood offering is introduced with וידבר יהוה אל מושה לאמר, “And YHWH spoke to Moses, saying...”. This introductory formula occurs throughout Leviticus, and is especially prominent in the Festival Calendar (Lev 23:1, 9, 23, 26, 33; 24:1). Thus it appears that 
the editor was careful to phrase the addition in language characteristic of its context. ${ }^{49}$ Of course we do not have the beginning or end of any of the 4QRP manuscripts, where it is theoretically possible that some sort of marker of a different speaker or different setting might have once existed, as in the book of Jubilees. If this is the case, the new narrative voice has certainly not left any impression upon the body of the texts. In fact, the example of 4Q365 23, which suggests that retention of the "voice" of the Pentateuch was intentional, militates against this possibility. It seems safe to assume, therefore, that the 4QRP texts throughout employed the same narrative voice as their pentateuchal Vorlage. When we turn to the issues of scope and coverage, definitive conclusions are precluded by the fragmentary nature of the $4 \mathrm{QRP}$ manuscripts. Segal assumes that 4Q364, 365, and 366 originally covered the entire Pentateuch; he suggests that 4Q367 may have contained only Leviticus, perhaps even in excerpted form, since the preserved fragments of that manuscript all contain material from Leviticus. ${ }^{50}$ That the composition reflected in the 4QRP manuscripts covered the entire Pentateuch was also the presumption of the texts' editors. ${ }^{51}$ But the fact is that the fragmentary nature of the 4QRP manuscripts makes any definitive determination of their scope impossible. Only one manuscript, 4Q365, contains material from all five books of the Pentateuch (4Q364 and 366 each contain material from four), and the preserved manuscript fragments contain only a small fraction of the pentateuchal text known from elsewhere. Since the beginnings and endings of the manuscripts have not been preserved, we are unable to determine whether any of the 4QRP manuscripts were coextensive with the Pentateuch or with any of its individual books. 
The same can be said regarding coverage. Segal's criterion suggests that, even if the 4 QRP texts had the same general scope as the Pentateuch, if they omitted significant amounts of material at any point, they could not be considered editions of the Pentateuch. Indeed, it is hard to imagine that an editor wishing to produce a version of the Torah would omit sizable amounts of material. ${ }^{52}$ To adhere to this criterion and at the same time to regard the $4 \mathrm{QRP}$ texts as editions of the Pentateuch requires a particular assumption with regard to the multiple instances of rearrangement that occur in the manuscripts; namely, that all the material that was dislodged from its original location because of rearrangement would have been relocated elsewhere, rather than simply omitted. For example, in the instance cited above where $4 \mathrm{Q} 365$ proceeds directly from the end of Numbers 4 to the beginning of Numbers 7 (frg. 28), what happened to Numbers 5-6? Were these chapters indeed moved to a different place in the composition, or is it possible that they were left out altogether? Tov has articulated the position that it is most likely that in such cases of rearrangement the intervening material was not omitted but relocated. ${ }^{53}$ On the other hand, Moshe Bernstein cautions that we should not presume that the 4QRP texts covered the whole Pentateuch (or whole individual books), a factor which for him, in line with Segal's criterion, suggests that the 4QRP texts are not to be considered expanded editions of the Torah. ${ }^{54}$ I would maintain that the argument from silence here unnecessarily closes off possibilities: granted, we should not assume that the 4 QRP texts covered the whole Pentateuch, but it is probably equally unjustified to assume that they did not. The main point, however, is that the poor preservation of the manuscripts forces us to leave the problem of what happened to this intervening material unresolved. 


\section{Implications}

In a sense, this study ends in frustration: I do not believe that in the current state of the texts we are able to decide with any confidence whether the $4 \mathrm{QRP}$ texts represent copies of the Pentateuch or compositions belonging to the rewritten Bible genre. Some features, such as the lack of a narrative voice distinguishable from that of the Pentateuch, clearly point towards pentateuchal status for the $4 \mathrm{QRP}$ texts. On the other hand, if the $4 \mathrm{QRP}$ texts do not cover the entire Pentateuch or entire books of the Pentateuch but omit sizeable amounts of material, it seems less likely that they were intended as copies of biblical books. While it might be convenient to assume complete coverage, insofar as it would then be easier to consider the $4 \mathrm{QRP}$ texts biblical, such an assumption is not really defensible. It should be kept in mind that, if any one of the 4QRP manuscripts did originally cover the entire Pentateuch, it would be unique among the Qumran scrolls, not just for its free treatment of the text of the Torah, but also for its length. Based on the length of the preserved fragments, the editors estimate that the length of e.g. 4Q365, if it did contain the entire Pentateuch, would be between 22 and $27 \mathrm{~m} .{ }^{55}$ This would be drastically longer than any other scrolls found at Qumran. ${ }^{56}$ It would also be our only example from Qumran of a full Torah copied in the same hand.${ }^{57}$ That one or more of the manuscripts represented only a part of a larger composition that covered the whole Pentateuch is possible for 4Q158 (which contains material from Genesis and Exodus only) and 4Q367 (Leviticus only), but not for the other manuscripts, which contain material from 4 or 5 books of the Pentateuch. No matter what the 4QRP texts were, they remain anomalous among the Qumran corpus. It seems that the most responsible option at this point is to live with uncertainty regarding these texts and to consider multiple 
possibilities without rushing to decide between them. I will close by exploring just two of such possibilities.

First, if we recognize the possibility that the $4 \mathrm{QRP}$ texts represent expanded editions of the Pentateuch, then we must reckon with the possibility that the degree of textual fluidity among versions of the Pentateuch in the Second Temple period was even greater than we thought. Such a possibility would in turn force us to rethink aspects of the canonical process. It has commonly been claimed that the text of the Pentateuch was already very stable in the late Second Temple period, since even alternate editions like the pre-Samaritan texts merely repeated material within the Pentateuch, and did not insert completely new material. ${ }^{58}$ If the $4 \mathrm{QRP}$ texts are versions of the Pentateuch, however, then, at least in some circles, the pentateuchal text was not as fixed as we thought.

The possible extent of such fluidity is illustrated most strikingly by $4 Q 365$, if the material now labeled 4Q365a is considered to be part and parcel of the larger manuscript. Though others have suggested that 4Q365a most likely belongs to the same composition as contained in the rest of $4 \mathrm{Q} 365,{ }^{59}$ to my knowledge no one has considered what the purpose might be of adding extensive temple-building instructions to a version of the Torah. First, I would maintain, as mentioned above, that we must be guided in this case by the manuscript evidence that suggests that $4 \mathrm{Q} 365$ a belongs with $4 \mathrm{Q} 365$. Second, the contents of the Torah itself may provide an explanation for why instructions for building a temple might be inserted into a version of the Torah. As it stands in other versions, the Torah includes instructions for the wilderness tabernacle, but not for the temple, the definitive locus of Israel's worship as a nation in its own land. It is not inconceivable that the editor of the text reflected in 4Q365 would have been so bothered by this absence that 
he took steps to correct it—much as, on a much smaller scale, the same editor inserted a law concerning the wood offering after the festival calendar of Leviticus 23 (4Q365 23). Lack of explicit divine origins for the blueprint for the first temple was clearly a problem for the Chronicler, who includes in his composition a scene in which David passes on to Solomon the instructions he had received from God concerning the temple: "All of it in writing from the hand of YHWH he showed me" (1 Chron 28:19). On the other hand, the author of the Temple Scroll both fills in this perceived gap in divine revelation and implicitly expresses dissatisfaction with the first temple (and the second) by presenting an elaborate temple plan revealed by God to Moses on Sinai. The plan is not for the Solomonic temple, from which it differs in numerous aspects, but for the ideal temple that, according to the author, should have been built. ${ }^{60}$ Given the parallels between TS and 4Q365/365a, it also seems possible that the purpose of inserting temple-building material into a version of the Pentateuch could have been more than simply exegetical concern over its absence. Perhaps in 4Q365, as in TS, the plan was for an ideal temple that, in its differences from Solomon's temple and its status as divine decree, would stand as witness to the fact that the temple that God intended had not yet been built. ${ }^{61}$ Both of these possible scenarios - exegetical gap-filling or criticism of the Solomonic temple (or both at once)—are purely speculative and are likely to remain so. Nonetheless, I believe they are worth contemplation as part of the challenge to our thinking that results from the mere possibility that $4 \mathrm{Q} 365$ represents an edition of the Pentateuch that included instructions for the building of a temple. 
At the other end of the spectrum, a second possibility emerges from consideration of two features of the 4QRP texts that seem to constitute a potential contradiction. Segal's list of criteria suggests that the absence of a distinctive narrative voice is consistent with a copy of the Pentateuch, whereas omission of sizeable sections of text would be more consistent with an extrabiblical composition. As noted, there is no sign that the 4QRP texts have any narrative voice besides that of the Pentateuch. The issue of coverage is fundamentally irresolvable given the fragmentary nature of the manuscripts. But perhaps it is worth considering the possibility that the original 4QRP texts had no distinct narrative voice but also omitted text; that is, that with regard to one criterion (voice) the 4QRP texts would appear biblical, but according to another criterion (coverage) they would appear to be something other than biblical. What would such a text be? It surely would not fit in with other examples of "excerpted" texts from Qumran, which generally appear to have been much more limited in scope and to have served a distinct purpose (e.g., as Tefillin). ${ }^{62}$

A closer parallel to this hypothetical collection of 4QRP texts that did not cover the entire Pentateuch might be found in 4Q252 (4QCommGen A). This striking text combines retellings or paraphrases of episodes in Genesis with some explicit exegetical comments (in one case even introducing an interpretation with פשרו, "its interpretation [concerns]," the formula that gave the Qumran pesharim their name). The text does not address every part of Genesis, but skips over major sections, dealing with only a few selected episodes. Moshe Bernstein has suggested that what we have in 4Q252 is the beginning of sequential, plain-sense commentary: the compiler seems to have strung together a series of difficult passages from Genesis, interpreting them sometimes by 
rewriting them and sometimes through explicit comment. ${ }^{63}$ There are obviously major differences between 4Q252 and the 4QRP texts, especially the use of paraphrase and explicit exegetical comment in the former, while the latter tend to accomplish their exegetical work through additions and juxtapositions as opposed to actual rewriting of the pentateuchal text. The $4 \mathrm{QRP}$ texts also include large sections of pentateuchal material without any sort of expansion or rearrangement. However, the phenomenon of commenting upon Scripture by re-presenting Scripture is the same in both. Perhaps $4 \mathrm{Q} 252$ offers a clue to what the purpose of the 4QRP texts might be, if indeed they did contain only parts of the Pentateuch. That is, the 4QRP texts, in this scenario, might represent some of the earliest precursors of sequential scriptural commentary: $:{ }^{64}$ only those pentateuchal texts which were of particular concern to the compiler (for whatever reason) were reproduced, sometimes with added material or in a new sequence that clarified their meaning. ${ }^{65}$ In a more developed stage represented by 4Q252, authors would have been more selective in including material, and would have exercised more freedom in recasting the actual words of Scripture and appending exegetical explanations to them.

To validate any of the scenarios described above would obviously require much more investigation, and will probably never be possible given the state of the texts. Yet the possibility itself - the struggle to understand these texts whose full context is lost to us - challenges us to rethink our assumptions about the development of Scripture and its interpretation in the Second Temple period. We may never be able to base firm conclusions regarding the state of the text of the Pentateuch upon the 4QRP texts, or to 
decide once and for all whether they are "biblical manuscripts," but we will continue to be tantalized by the range of possibilities they afford.

${ }^{1}$ This essay is a revised version of a paper presented in the Qumran Section of the SBL Annual Meeting in Washington, D.C., November 2006. I would like to extend my thanks to Jim VanderKam, Gene Ulrich, Peter Grund, and Andrew Teeter, each of whom was kind enough to read one or more drafts of this paper; to Moshe Bernstein, whose generosity in conversation has helped me to further refine my own perspective on the 4QRP texts; and to Eibert Tigchelaar and DSD's anonymous referee for their helpful comments and suggestions.

${ }^{2}$ See Dwight D. Swanson, The Temple Scroll and the Bible: The Methodology of 11QT (STDJ 14; Leiden: Brill, 1995), 4.

${ }^{3}$ Yigael Yadin, The Temple Scroll (3 vols.; Jerusalem: Israel Exploration Society, 1977-83), 1.20.

${ }^{4}$ Emanuel Tov and Sidnie White, "Reworked Pentateuch," in Qumran Cave 4, VIII (by Harold Attridge, et al.; DJD 13; Oxford: Clarendon, 1994), 187-351, at p. 191; Emanuel Tov, "Biblical Texts as Reworked in Some Qumran Manuscripts with Special Attention to 4QRP and 4QParaGen-Exod," in The Community of the Renewed Covenant: The Notre Dame Symposium on the Dead Sea Scrolls (eds. Eugene Ulrich and James C. VanderKam; Notre Dame, Ind.: University of Notre Dame Press, 1994), 111-34, at pp. 113-14.

${ }^{5}$ See Eugene Ulrich, "The Dead Sea Scrolls and the Biblical Text," in The Dead Sea Scrolls after Fifty Years: A Comprehensive Assessment (eds. Peter W. Flint and James C. VanderKam; Leiden: Brill, 1998), 1.79-100, at p. 88; James C. VanderKam, "Questions of Canon Viewed through the Dead Sea Scrolls," in The Canon Debate (eds. Lee Martin McDonald and James A. Sanders; Peabody, Mass.: Hendrikson, 2002), 91-109, at pp. 96-100; Michael Segal, "4QReworked Pentateuch or 4QPentateuch?," in The Dead Sea Scrolls: Fifty Years After Their Discovery (eds. Lawrence H. Schiffman, Emanuel Tov, and James C. VanderKam; Jerusalem: Israel Exploration Society/Shrine of the Book, Israel Museum, 2000), 391-99, at pp. 394-95; Eugene Ulrich, "The Text of the Hebrew Scriptures at the Time of Hillel and Jesus," in Congress Volume Basel 2001 (ed. Andre Lemaire; VTSup 92; Leiden: Brill, 2002), 85-108, at pp. 102-3. 
${ }^{6}$ Segal argues that 4Q158 is fundamentally different in its way of dealing with the biblical text from the other 4QRP manuscripts; thus he classifies it as a type of rewritten Bible, but regards 4Q364-367 as copies of the Pentateuch; see Segal, "4QReworked Pentateuch."

${ }^{7}$ Emanuel Tov, "Three Strange Books of the LXX: 1 Kings, Esther, and Daniel Compared with Similar Rewritten Compositions from Qumran and Elsewhere," in Die Septuaginta. Texte, Kontexte, Lebenswelten (eds. M. Karrer and W. Kraus; Tübingen: Mohr Siebeck, 2007 (forthcoming)); Emanuel Tov, "Reflections on the Many Forms of Hebrew Scripture in Light of the LXX and 4QReworked Pentateuch," (forthcoming in the IOSOT Congress Volume, Vienna, 2007).

${ }^{8}$ Moshe J. Bernstein, "'Rewritten Bible': A Generic Category Which Has Outlived its Usefulness?," Textus 22 (2005): 169-96, at pp. 182-83.

${ }^{9}$ Michael Segal, "Between Bible and Rewritten Bible," in Biblical Interpretation at Qumran (ed. Matthias Henze; Grand Rapids: Eerdmans, 2005), 10-29, at pp. 15-16.

${ }^{10}$ See VanderKam, "Questions of Canon," 93. For an overview of the entire issue, see Eugene Ulrich, "The Notion and Definition of Canon," in The Canon Debate (eds. Lee Martin McDonald and James A. Sanders; Peabody, Mass.: Hendrickson, 2002), 21-35.

${ }^{11}$ See, most notably, James C. VanderKam, "The Wording of Biblical Citations in Some Rewritten Scriptural Works," in The Bible As Book: The Hebrew Bible and the Judaean Desert Discoveries (eds. Edward D. Herbert and Emanuel Tov; London: British Library, 2002), 41-56, at p. 52. See also Eugene Ulrich, The Dead Sea Scrolls and the Origins of the Bible (Grand Rapids: Eerdmans, 1999), 19; Sidnie White Crawford, "The 'Rewritten' Bible at Qumran: A Look at Three Texts," ErIsr 26 (1999): 1-8 (Eng.), at p. 1; George J. Brooke, "The Rewritten Law, Prophets and Psalms: Issues for Understanding the Text of the Bible," in The Bible as Book: The Hebrew Bible and the Judaean Desert Discoveries (eds. Edward D. Herbert and Emanuel Tov; London: British Library, 2002), 31-40, at p. 31.

${ }^{12}$ James C. VanderKam and Peter W. Flint, The Meaning of the Dead Sea Scrolls (London: T\&T Clark, 2005), 156.

${ }^{13}$ VanderKam and Flint describe a "scriptural" work, in the context of the Scrolls, as "a writing that was considered divinely revealed, uniquely authoritative, and believed to be of ancient origin"; see 
VanderKam and Flint, Meaning, 156. I believe that this definition is basically sound, although what precisely is meant by "uniquely authoritative" is not clear to me.

${ }^{14}$ See e.g. James VanderKam, "Authoritative Literature in the Dead Sea Scrolls," DSD 5 (1998): $382-402$.

${ }^{15}$ Segal, "4QReworked Pentateuch," 391-92; George J. Brooke, "4Q158: Reworked Pentateuch ${ }^{\mathrm{a}}$ or Reworked Pentateuch A?," DSD 8 (2001): 219-41.

${ }^{16}$ Segal, "4QReworked Pentateuch," 392.

${ }^{17}$ In only two cases do different MSS of 4QRP share a reading that is not attested elsewhere: 4Q364 173 and 4Q365 81 both read הארון for MT, SP ארון in Exod 26:34; and 4Q158 17 and 4Q364 5 ii 13 both read ויואמר for MT SP LXX ויקרא in Gen 32:31. See Tov and White, DJD 13.188-90.

${ }^{18}$ Tov and White, DJD 13.191.

${ }^{19}$ Segal, "4QReworked Pentateuch," 392; Brooke, "4Q158," 223-24.

${ }^{20}$ Brooke, "4Q158," 228-34.

${ }^{21}$ It should be noted that this issue appears in a different light if the 4QRP texts are regarded as copies of the Torah. Crawford puts the matter succinctly: If $4 Q R P$ "is the result of scribal intervention in a previously established text rather than a composition by an author, then the division into separate compositions is less meaningful. Each manuscript is simply the product of more or less scribal intervention" (or, one might add, of different scribal interventions). See Crawford, "'Rewritten' Bible at Qumran," 6.

${ }^{22}$ Segal, "Between Bible and Rewritten Bible," 15.

${ }^{23}$ Emanuel Tov, "The Textual Status of 4Q364-367 (4QPP)," in The Madrid Qumran Congress: Proceedings of the International Congress on the Dead Sea Scrolls, Madrid 18-21 March 1991 (eds. Julio Trebolle Barrera and Luis Vegas Montaner; STDJ 11; Leiden: Brill, 1992), 1.43-82. In the same article, Tov notes that $4 \mathrm{Q} 365$ 's textual affiliations are less clear-it does not share any major additions or changes with SP, nor is it particularly close to SP in minor details - while 4Q366 and 4Q367 do not contain enough material to determine their textual character. In this connection, it is worth pointing out that $4 \mathrm{Q} 365$ does seem to share with the pre-Samaritan text $4 \mathrm{QNum}{ }^{\mathrm{b}}$ the exegetical join of Numbers 27 and 36, but the 
precise method by which the two texts are fused is different for each (see below, p. XX). It would thus seem that 4Q365 does show at least some connections to the SP traditions, but that these connections are exegetical rather than textual.

${ }^{24}$ The conclusions of the editor of 4Q158 notwithstanding, the statement "and he blessed him there" does not refer to a new, unrecorded blessing. It may refer back in summary fashion to Jacob's request for a blessing and his reception of a new name in Gen 32:27-29 or, as Segal notes, it may simply indicate that the man said farewell to Jacob. See NAB, "With that, he bade him farewell," NJPSV, "And he took leave of him there," and Michael Segal, "Biblical Exegesis in 4Q158: Techniques and Genre," Textus 19 (1998): 45-62, at p. 59. The connection, of course, is that a greeting or parting word would often be accompanied by a blessing; see E. A. Speiser, Genesis (AB 1; Garden City, N.Y.: Doubleday, 1964), 202. Compare also the etymology for English "goodbye" as a contraction of "God be with you" (OED, s.v.).

${ }^{25}$ On the technique of Wiederaufnahme or repetitive resumption to bracket an insertion, see Michael A. Fishbane, Biblical Interpretation in Ancient Israel (Oxford: Clarendon, 1985), 85-86.

${ }^{26}$ The Hebrew texts of 4QRP presented here follow the transcriptions in Donald W. Parry and Emanuel Tov (eds.), Parabiblical Texts (The Dead Sea Scrolls Reader 3; Leiden: Brill, 2005). Spacing and lineation have been retained, though I have not included indications of possible and probable letters. Translations are my own.

${ }^{27}$ See Tov and White, DJD 13.270; David Carr, "Method in Determination of Direction of Dependence: An Empirical Test of Criteria Applied to Exodus 34,11-26 and its Parallels," in Gottes Volk am Sinai: Untersuchungen zu Ex 32-34 und Dtn 9-10 (eds. Matthias Köckert and Erhard Blum; Veröffentlichungen der Wissenschaftlichen Gesellschaft für Theologie 18; Gütersloh: Kaiser, 2001), 10740, at p. 118.

${ }^{28}$ The wood offering is attested in Nehemiah $(10: 35 ; 13: 31)$ and in Josephus (J.W. 2:245), as well as in the Temple Scroll (cols. 23-24), where the legislation contains some close parallels to the version in 4Q365. For a valuable discussion, see Yadin, Temple Scroll, 1.128-31. The Festival of New Oil also appears in the Temple Scroll (cols. 21-22). Yadin actually considered 4Q365 23 (along with 2 fragments now classified as part of 4Q365a) to be part of another copy of the Temple Scroll; see Yadin, Temple Scroll, 1.8. However, since the text of 11QT on the wood offering is much longer than the text of 4Q365 
23 , the relationship between the two must be more complicated than that of copy and exemplar; see Tov and White, DJD 13.294-95.

${ }^{29}$ Although in every physical respect (hand, leather, etc.) the five fragments classified as 4Q365a match the rest of 4Q365, the editors separated them from the 4QRP group because they contain no biblical material. See Sidnie White, "4Q365a," in Qumran Cave 4, VIII (by Harold Attridge, et al.; DJD 13; Oxford: Clarendon, 1994), 319-34. Such an approach, however, is based on a priori assumptions about what a given text (in this case, a "Reworked Pentateuch" text) could or could not contain. As others have argued, better procedure would be to stick to the physical evidence and reckon with the likelihood that the materials in 4Q365a are part of the composition reflected in 4Q365. See especially Florentino García Martínez, "Multiple Literary Editions of the Temple Scroll?," in The Dead Sea Scrolls: Fifty Years After Their Discovery (eds. Lawrence H. Schiffman, Emanuel Tov, and James C. VanderKam; Jerusalem: Israel Exploration Society/Shrine of the Book, Israel Museum, 2000), 364-71, at pp. 369-70.

${ }^{30}$ Julius Wellhausen, Prolegomena to the History of Israel (Edinburgh: A \& C Black, 1885; reprint, Atlanta: Scholars, 1994), 234. On 4QJudga, with further evidence for considering its shorter text to be original, see Ulrich, Dead Sea Scrolls, 105.

${ }^{31}$ On 1 Samuel 16-18 see Emanuel Tov, "The Composition of 1 Samuel 16-18 in the Light of the Septuagint Version," in Empirical Models for Biblical Criticism (ed. Jeffrey H. Tigay; Philadelphia: University of Pennsylvania Press, 1985), 98-130, at pp. 98-99. For the textual history of Jeremiah, see J. Gerald Janzen, Studies in the Text of Jeremiah (HSM 6; Cambridge: Harvard University Press, 1973); Emanuel Tov, "The Literary History of the Book of Jeremiah in the Light of Its Textual History," in Empirical Models for Biblical Criticism (ed. Jeffrey H. Tigay; Philadelphia: University of Pennsylvania Press, 1985), 211-37.

${ }^{32}$ See now Tov, "Three Strange Books."

${ }^{33}$ These two pericopes seem also to have been combined in $4 \mathrm{QNum}{ }^{\mathrm{b}}$, but in a different way. There, Num 36:2 and 36:4 appear on either side of a lacuna of 13 lines. Since vv. 2 and 4 are both expanded in this manuscript to make mention of Eleazar the priest, who otherwise appears only in chapter 27, the editor postulates that the lacuna, much too large for the missing text of Num 36:2-4, contained material from chapter 27. See Nathan Jastram, "4QNumb," in Qumran Cave 4, VII: Genesis to Numbers (by 
Eugene Ulrich, et al.; DJD 12; Oxford: Clarendon, 1994), 205-67, at pp. 260-64; Emanuel Tov, "Rewritten Bible Compositions and Biblical Manuscripts, with Special Attention to the Samaritan Pentateuch," DSD 5 (1998): 334-54, at p. 353.

${ }^{34}$ As Segal notes, the solution proposed by Tov and Crawford, that both laws mention a "sojourner" of some sort, fails to convince because each law uses a different Hebrew word (גר in Lev 24:22; תושב in Lev 25:40). See Tov and White, DJD 13.339; Segal, "4QReworked Pentateuch," 397.

${ }^{35}$ These examples as well as two others (Jeremiah 10 and the book of Proverbs) are mentioned by Segal, "Between Bible and Rewritten Bible," 19-20. Tov adduces additional cases of rearrangement in the LXX translation of 1 Kings (= 3 Kingdoms); see Tov, "Three Strange Books."

${ }^{36}$ For a detailed discussion of the issues surrounding the tabernacle pericope, see Anneli Aejmelaeus, "Septuagintal Translation Techniques--A Solution to the Problem of the Tabernacle Account," in Septuagint, Scrolls and Cognate Writings (eds. George J. Brooke and Barnabas Lindars; SBLSCS 33; Atlanta: Scholars, 1992), 381-402. See also Ulrich, Dead Sea Scrolls, 102. On Jeremiah 46-51, see Beat Huwyler, Jeremia und die Völker: Untersuchungen zu den Völkersprüchen in Jeremia 46-49 (FAT 20; Tübingen: Mohr Siebeck, 1997).

${ }^{37}$ Segal, "Between Bible and Rewritten Bible," 16. See also Tov, "Reflections." Tov notes that the kinds of changes that appear in expanded forms of biblical texts (his examples are LXX 3 Kingdoms, LXX Esther, and LXX Daniel) appear not only in the SP group and the 4QRP texts, but in TS, Jubilees, and the Genesis Apocryphon as well. Tov does not address clearly, however, the issue of why it is only 4QRP, and not any of these other texts, that is to be considered an edition of the Pentateuch.

38 Yadin, Temple Scroll, 1.71-88.

${ }^{39}$ The usefulness of such a continuum has been noted by VanderKam, "Wording of Biblical Citations," 46. Similarly, George Brooke speaks of a "sliding scale" of divergence from known biblical versions. See Brooke, "Rewritten Law," 36.

${ }^{40}$ Segal, "Between Bible and Rewritten Bible," 18-20.

${ }^{41}$ Segal, "Between Bible and Rewritten Bible," 13-14. In light of this argument, I have difficulty understanding Segal's position that 4Q158 should be separated from the other 4QRP manuscripts and 
identified as containing an extrabiblical composition on the basis of differences in the way the pentateuchal Vorlage is reworked. (See Segal, "4QReworked Pentateuch," 396.) According to Segal's own criteria, more drastic reworking should not eliminate the possibility that a text is a pentateuchal manuscript. With regard to the related point of whether 4Q158 represents a qualitatively different type of reworking than the other 4QRP manuscripts (whether or not these are biblical), I do not believe that Segal's argument is convincing. Although he has examined the types of reworking in 4Q158 in some detail, he has not demonstrated that these same features are absent in the other manuscripts; see Segal, "Biblical Exegesis." George Brooke has observed that in fact several of the distinctive types of rewriting that appear in 4Q158 can also be seen in 4Q364 and 365; Brooke, "4Q158," 239-40. A more thorough examination of the textual reworking in all the 4QRP manuscripts would be necessary to settle the issue definitively.

${ }^{42}$ Not all of Segal's criteria are equally helpful. For example, he argues that a copy of a biblical book must be in the original language of that book; see Segal, "Between Bible and Rewritten Bible," 17. Thus, according to him, the Genesis Apocryphon and Josephus' Antiquities are not copies of the Bible because they are written in Aramaic and Greek, respectively. It is clear on other grounds that GenAp and the Antiquities are not intended as copies of biblical books, but insofar as the Targumim and the LXX were considered to represent the biblical books faithfully, language alone does not seem an adequate criterion for making this decision. Similarly, Segal asserts that only works that should be classified as "rewritten Bible" have a "tendentious editorial layer"; Segal, "Between Bible and Rewritten Bible," 25. This assertion is belied by the textual histories of, for example, the books of Jeremiah and Esther: the later editions of both of these books (represented in MT Jeremiah and LXX Esther) show clear signs of purposeful, goal-oriented editing. For a similar critique of this last criterion, see Bernstein, "Rewritten Bible," 193.

${ }^{43}$ Segal, "Between Bible and Rewritten Bible," 22-23.

${ }^{44}$ Segal, "Between Bible and Rewritten Bible," 20-21.

${ }^{45}$ It is perhaps worthy of note that Jubilees and the Temple Scroll, when taken together, in fact cover most of the Torah from Genesis through Deuteronomy. This fact has led Wacholder to argue that the two books were in fact composed as volumes I and II of the new Torah of the Qumran sectarians; see Ben Zion Wacholder, "The Relationship between 11Q Torah (The Temple Scroll) and the Book of Jubilees: One Single or Two Independent Compositions," in Society of Biblical Literature 1985 Seminar Papers (ed. 
Kent Harold Richards; Atlanta: Scholars Press, 1985), 205-216. Such an explanation, however, fails to consider important differences between the two works. The most salient difference is perhaps that of speaker: both Jubilees and the Temple Scroll are presented as revelation from Sinai, but in Jubilees it is the Angel of the Presence who speaks, whereas in the Temple Scroll God himself is the speaker. It seems unlikely that the two halves of a single composition would fail to adhere to the same literary fiction. Furthermore, Schiffman has pointed out numerous differences in emphasis and some outright contradictions in the sacrificial systems of the two works, divergences which make it difficult to imagine that they are parts of the same composition; see Lawrence H. Schiffman, "The Sacrificial System of the Temple Scroll and the Book of Jubilees," in Society of Biblical Literature 1985 Seminar Papers (ed. Kent Harold Richards; Atlanta: Scholars Press, 1985), 217-233.

Even if Jubilees and the Temple Scroll were not composed to go together, it might be possible that some Jews of the Second Temple period read them as complementary and thus as constituting a new version of the Torah. However, I would argue that even this would not make Jubilees and the Temple Scroll new editions of pentateuchal books; rather, they are new literary works that cover much of the same material as the Pentateuch. An analogous case in my mind would be the books of Chronicles, which, although they tell much the same story as the books of Samuel and Kings and use those books as a source, were not considered a new edition of Samuel-Kings such that they could replace the former, but rather were regarded as a separate work. On this point, see Segal, "Between Bible and Rewritten Bible," 16-17.

${ }^{46}$ Segal, "Between Bible and Rewritten Bible," 23-24. Alexander has previously made a similar observation - that rewritten Bible texts are selective in their reuse of the biblical source text. See Philip Alexander, "Retelling the Old Testament," in It is Written: Scripture Citing Scripture (eds. D. Carson and H.G.M. Williamson; Cambridge: Cambridge University Press, 1988), 99-121, at pp. 116-18.

${ }^{47}$ Segal, "4QReworked Pentateuch," 394.

${ }^{48}$ Sidnie Crawford, "How Archaeology Affects the Study of Texts: Reflections on the Category 'Rewritten Bible' at Qumran," in Caves of Enlightenment: Proceedings of the American Schools of Oriental Research Dead Sea Scrolls Jubilee Symposium (1947-1997) (ed. James H. Charlesworth; North Richland Hills, Tex.: BIBAL Press, 1998), 39-53, at p. 52. 
${ }^{49} \mathrm{In}$ a forthcoming article on the 4QRP texts, Moshe Bernstein cites this mimicry of the pentateuchal formula as of critical importance to our understanding of 4Q365 and as strong (though not unimpeachable) evidence that 4Q365 might constitute a copy of the Pentateuch. See M.J. Bernstein, "What Has Happened to the Laws? The Treatment of Legal Material in 4QReworked Pentateuch." I am grateful to Prof. Bernstein for sharing two drafts of his article with me prior to its publication.

${ }^{50}$ Segal, "4QReworked Pentateuch," 394, 399. Segal does not address what the function or purpose of such an excerpted text might be. Note the concerns on this point of Moshe Bernstein, "What Has Happened to the Laws?"

${ }^{51}$ Tov and White, DJD 13.191. See also Emanuel Tov, "4QReworked Pentateuch: A Synopsis of its Contents," $R Q 64$ (1995): 647-53, at p. 647.

52 The rarity of plausible examples of deliberate omission in the documentable history of the biblical text is indicated by the fact that Tov does not include any form of minus among the types of changes he discusses in a section entitled "Readings Intentionally Created by Scribes"; see Emanuel Tov, Textual Criticism of the Hebrew Bible (2nd ed.; Minneapolis: Fortress, 2001), 258-85. One of the only omissions of any size that I am aware of that can be regarded as deliberate is the excision in MT of two stichs from Deut 32:43 as preserved in LXX and 4QDeut". One of these reads והשתחוו לו כל אלהים, bow down to him, all you gods"; it seems clear that this was removed because of its polytheistic implications. For a convenient discussion, see Bernard M. Levinson, "Deuteronomy," in The Jewish Study Bible (eds. Adele Berlin and Marc Zvi Brettler; Oxford: Oxford University Press, 2004), at Deut 34:43.

${ }^{53}$ Tov, "Biblical Texts as Reworked," 128.

${ }^{54}$ Bernstein, "What Has Happened to the Laws?"

${ }^{55}$ Tov and White, DJD 13.192.

${ }^{56}$ The longest scroll so far identified is the Temple Scroll, whose extant attached columns measure $8.15 \mathrm{~m}$ and whose total length was probably around $8.75 \mathrm{~m}$. The great Isaiah Scroll (1QIsa $\left.{ }^{\mathrm{a}}\right)$ measures 7.34 m. See Yadin, Temple Scroll, 1.10. Aside from the 4QRP manuscripts, the longest reconstructed length for a scroll is $16.3-17.6 \mathrm{~m}$ for $4 \mathrm{QJer}$, still a full $5 \mathrm{~m}$ or more shorter than the length posited for $4 \mathrm{QRP}$; several other scrolls may originally have been in the 10-11 m range. For a chart, see Emanuel Tov, Scribal 
Practices and Approaches Reflected in the Texts found in the Judean Desert (STDJ 64; Leiden: Brill, 2004), 76.

${ }^{57}$ The Qumran corpus contains several examples of scrolls containing two books of the Pentateuch: 4QGen-Exod ${ }^{\mathrm{a}}$, 4QpaleoGen-Exod ${ }^{1}$, 4QExod-Lev ${ }^{\mathrm{f}}$, 4QLev-Num ${ }^{\mathrm{a}}$. It should be noted that Mur 1 contains fragments from Genesis, Exodus, and Numbers in the same hand, and thus may have contained the entire Torah, either in a single scroll or in two or more similarly prepared scrolls. See Emanuel Tov, "Copying of a Biblical Scroll," JRH 26 (2002): 189-209, at p. 207. Menachem Haran has argued, principally on the basis of rabbinic remarks, that large scrolls that contained the entire Torah were unknown in the Second Temple period and that each of the five books was written on a separate scroll; see Menachem Haran, "Torah and Bible Scrolls in the First Centuries of the Christian Era," Shnaton 10 (198690): 93-106 (Hebrew). While Haran convincingly demonstrates that the use of scrolls containing individual books of the Torah persisted into the Talmudic period, the corollary claim that scrolls containing the entire Torah did not exist before this period is in essence an argument from silence. As Tov observes, the evidence from Qumran "neither supports nor contradicts the existence of such large scrolls"; Tov, "Copying of a Biblical Scroll," 207. In any case, even the existence at Qumran of scrolls containing two books of the Torah seems to militate against Haran's argument that, prior to the development of complete Torah scrolls, each book was written on its own separate scroll.

${ }^{58}$ See for example Crawford, "'Rewritten' Bible at Qumran," 3; Julio Trebolle Barrera, "Origins of a Tripartite Old Testament Canon," in The Canon Debate (eds. Lee Martin McDonald and James A. Sanders; Peabody, Mass.: Hendrikson, 2002), 128-45, at p. 136.

${ }^{59}$ Besides García Martínez (see n. 29 above), see Bernstein, "What Has Happened to the Laws?," and Tov, "Three Strange Books."

${ }^{60}$ See Molly M. Zahn, "New Voices, Ancient Words: The Temple Scroll's Reuse of the Bible," in Temple and Worship in Biblical Israel (ed. John Day; Library of Hebrew Bible/Old Testament Studies 422; London: T \& T Clark, 2005), 435-58, at p. 450; George J. Brooke, "The Ten Temples in the Dead Sea Scrolls," in Temple and Worship in Biblical Israel (ed. John Day; Library of Hebrew Bible/Old Testament Studies 422; London: T \& T Clark, 2005), 417-34, at pp. 424-25. On the differences between the 
Solomonic temple and the temple as imagined by TS, see Lawrence H. Schiffman, "The Construction of the Temple According to the Temple Scroll," RQ 17 (1996): 555-71, at p. 571.

${ }^{61}$ The precise nature of the relationship between $4 \mathrm{Q} 365$ and TS is a complicated issue that cannot be addressed in detail here. The extensive verbatim parallels between 4Q365a 2 ii and 11QT 41 make clear that there must be a literary connection between the two texts; at the very least they share a common source for this section. On the other hand, none of the other fragments of 4Q365a find direct parallels in TS, leading Crawford to argue that, if 4Q365a was another copy of TS (as the close correspondence between 11QT 41 and 4Q365a 2 ii might suggest), it must represent a different recension of the composition. Hence the DJD designation of 4Q365a as “4QTemple?”; see White, DJD 13.320, 330. If 4Q365 and 365a belong to a single composition, however, it is clear that that composition cannot be described as a recension of TS. Whether or to what extent one text might be the source of the other remains to be explored. Earlier studies of TS that discuss the PAM 43.366 fragments $(=4 \mathrm{Q} 365$ 23; 4Q365a 2, 3) may be helpful in this regard in that several consider in detail the textual relationship between these three fragments and TS (Yadin considered the fragments to represent another copy of TS). However, since they all appear prior to the publication of the three fragments in DJD 13 as part of 4Q365 and 365a, they do not sufficiently address the larger manuscript context of the fragments, which remains a significant issue. The studies include Yadin, Temple Scroll, 2.160-64, 172-77, Supplementary Plates 38, 40; Ben Zion Wacholder, The Dawn of Qumran (HUCM 8; Cincinnati: Hebrew Union College Press, 1983), 205-6; Baruch Levine, "The Temple Scroll: Aspects of its Historical Provenance and Literary Character," BASOR 232 (1978): 5-23, at pp. 5-6; Hans-Aage Mink, "The Use of Scripture in the Temple Scroll and the Status of the Scroll as Law," SJOT 1 (1987): 20-50, at pp. 23-34; Michael Owen Wise, A Critical Study of the Temple Scroll from Qumran Cave 11 (SAOC 49; Chicago: Oriental Institute of the University of Chicago, 1990), 44-59; Ben Zion Wacholder, "The Fragmentary Remains of 11QTorah (Temple Scroll)," HUCA 62 (1991): 1-116. ${ }^{62}$ See Bernstein, "What Has Happened to the Laws?" On the various types of excerpted texts at Qumran, see Emanuel Tov, "Excerpted and Abbreviated Biblical Texts from Qumran," RQ 64 (1995): 581600.

${ }^{63}$ Moshe J. Bernstein, "4Q252: From Re-Written Bible to Biblical Commentary," JJS 45 (1994): $1-27$. 
${ }^{64}$ Bernstein himself refers elsewhere to $4 \mathrm{QRP}$ as representing the "first steps toward the commentary genre," although without reference to 4Q252 or the issue of possibly omitted material. See Moshe J. Bernstein, "Pentateuchal Interpretation at Qumran," in The Dead Sea Scrolls after Fifty Years (eds. Peter W. Flint and James C. VanderKam; Leiden: Brill, 1998), 1.128-59, at p. 134.

${ }^{65}$ It must be observed that such selectivity would seem to represent a major new way of presenting scriptural interpretation. Both expansive versions of biblical books and rewritten Bible texts embed their exegesis within an independent or freestanding literary work. An "excerpted" text, such as the $4 \mathrm{QRP}$ texts might be in this scenario, also embeds its exegesis in the sense that there are no explicit interpretive comments. However, insofar as such excerpting interrupts the logical organization of the larger text without providing any new cues for how the shorter text might be read sequentially, the compiler seems to make no attempt to present the new text as an independent, coherent literary work: it is meant to be understood only by reference to the full version of the text it interprets. 